\title{
Egg shell morphology of an amblyceran louse, Hohorstiella rampurensis (Phthiraptera) infesting ring dove, Streptopelia decaocta
}

\author{
Padam Singh, J agirti M adan and Nidhi G upta* \\ Department of Zoology, Govt. Raza P. G. College, Rampur -244901 (U.P.), INDIA \\ *Corresponding author. E-mail: drnidhigpta@gmail.com
}

Received: July 28, 2013; Revised received: D ecember 17, 2015; Accepted: March 21, 2016

\begin{abstract}
Scanning electron microscopy (SEM) study showed that miniature rice grain like egg shell of Hohorstiella rampurensis was covered by obliquely placed opercular disc. The apophyses were present only on one side of the egg shell. There were 25-35 long elongated rod like apophyses (apically turned), which were arranged in 3-4 rows and occurred in pair. The nature of egg shell of $\mathrm{H}$. rampurensis characteristically differed from that of $\mathrm{H}$. lata (the only species of Hohorstiella studied, so far). The study further indicates about the role of egg morphology as a guide to louse taxonomy.
\end{abstract}

Keywords: Amblycera, Egg shell morphology, Lice, Microtopography, Phthiraptera

\section{INTRODUCTION}

The markings/ projections present on the egg cases of Phthiraptera are often species specific and can be used to differentiate the species (Balter, $1968 \mathrm{a}, \mathrm{b}$ ). Selected workers have made attempts to record the microtopography of certain avian lice with the help of SEM (Bilinski and Jankowska, 1987, Castro et al., 1996, Zawadzka et al., 1997, Saxena et al., 2000, Kumar et al., 2003, 2007, Beg et al., 2004, Gupta et al., 2004, 2009, Rajput et al., 2010). The present report furnishes information on the egg shell morphology of an amblyceran louse, Hohorstiella rampurensis infesting ring dove, Streptopelia decaocta.

\section{MATERIALS AND METHODS}

Feathers bearing egg of $\mathrm{H}$. rampurensis were gently cut form host body and teased out with the help of extremely sharpened entomological pins. Eggs were subjected to Scanning Electron Microscopy (SEM) studies following the method adopted by Gupta et al., (2009).

\section{RESULTS}

Eggs of $H$. rampurensis are generally found laid on the feathers belonging to nape, neck and head (fore parts) of the body. This louse lays eggs on the basal portion of the feathers on either side of calamus. Generally 1-2 eggs were observed on feathers. The eggs were glued mediolaterally. Thus, they lay straight and were inclined at $0-5^{\circ}$, with respect to rachis. The egg shells of $\mathrm{H}$. rampurensis is a miniature rice grain (measuring 0.74$0.76 \mathrm{~mm}$ in length and $0.18-0.19 \mathrm{~mm}$ in width) (Plate I, Photo 1) like in appearance. The egg mouth was covered by a conical obliquely placed opercular disc (Plate I, Photo
2). However, the opercular disc was quite smooth and devoid of sclupturing/ polar thread. Twelve to fourteen small button shaped micropyles ( $7 \mathrm{~mm}$ in diameter) were found arranged along the opercular rim (Plate I, Photo 3). The egg chorion was quite smooth but bore numerous apophyses. However, the apophyses were present only on one side of the egg shell (the side which was glued to the feathers remained devoid of apophyses) (Plate II, Photo 1). At the apical end (near egg mouth) there occurred 25-35 long elongated (0.03-0.05 mm long) rod like apophyses (apically turned) which were arranged in three to four rows and occured in pairs. Rest of the chorion was found studded with small sized apophyses which remained curved (Plate II, Photo 3). These apophyses also occurred in pairs and were more or less equally spaced. However, the basal portion of the egg remained smooth (devoid of apophyses). The rear end of the egg shell carried the stigma in the form of 3 to 4 protuberances (Plate II, Photo 2). Thus, the eggshell of $\mathrm{H}$. rampurensis exhibited certain peculiar features which can help in differentiating the species during taxonomic categorization.

\section{DISCUSSION}

Eggs of avian lice often exhibit markings/ sculpturings which are quite species specific and can be used to differentiate the genera and species. Balter (1968 a , b) have emphasized the role of egg morphology as a guide to louse taxonomy. The nature of egg shells of different species belonging to same genus have been best studies in case of genus $M$ enacanthus (e.g. $M$. stramineas, $M$. gonophaeus, $M$. cornutus and $M$. abdominalis) by workers like Balter (1968 a,b), Bilinsky and Jankoswsa 

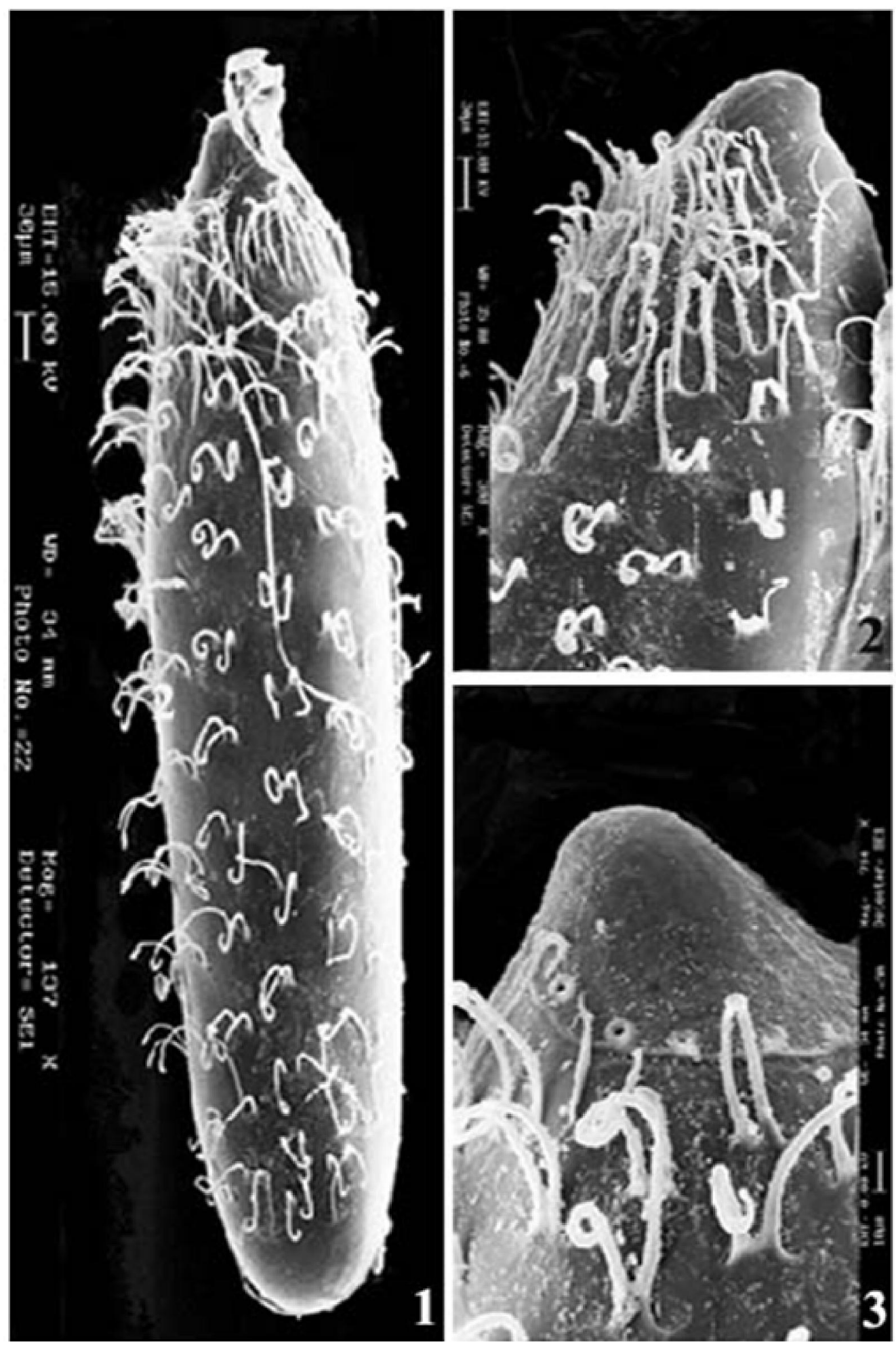

Plate 1. SEM photographs of the eggs of Hohorstiella rampurensis showing- 1. Entire eggshell (x137), 2. Enlarged opercular end showing the nature of apophyses (x240), 3. Enlarged view of the opercular end (x315).

(1987), Zadewaka et al. (1997), Beg et al. (2004), Kumar et al. (2007) and Gupta et al. (2009). The egg shells of aforesaid species of M enacanthus exhibit differences in the nature of apophyses, polar thread, opercular disc and the micropyles. As far as the egg of genus $\mathrm{H}$ ohorstiella is concerned, only one species (pigeon louse, H ohorstiella lata) has been studied so far (Saxena et al., 2000). The egg shells of $\mathrm{H}$. lata bore numerous spine like apophyses which were characteristically different from $H$. rampurensis. In case of $H$. rampurensis, the apophyses were present only on one side of the egg shell. The apophyses of apical region were quite long 

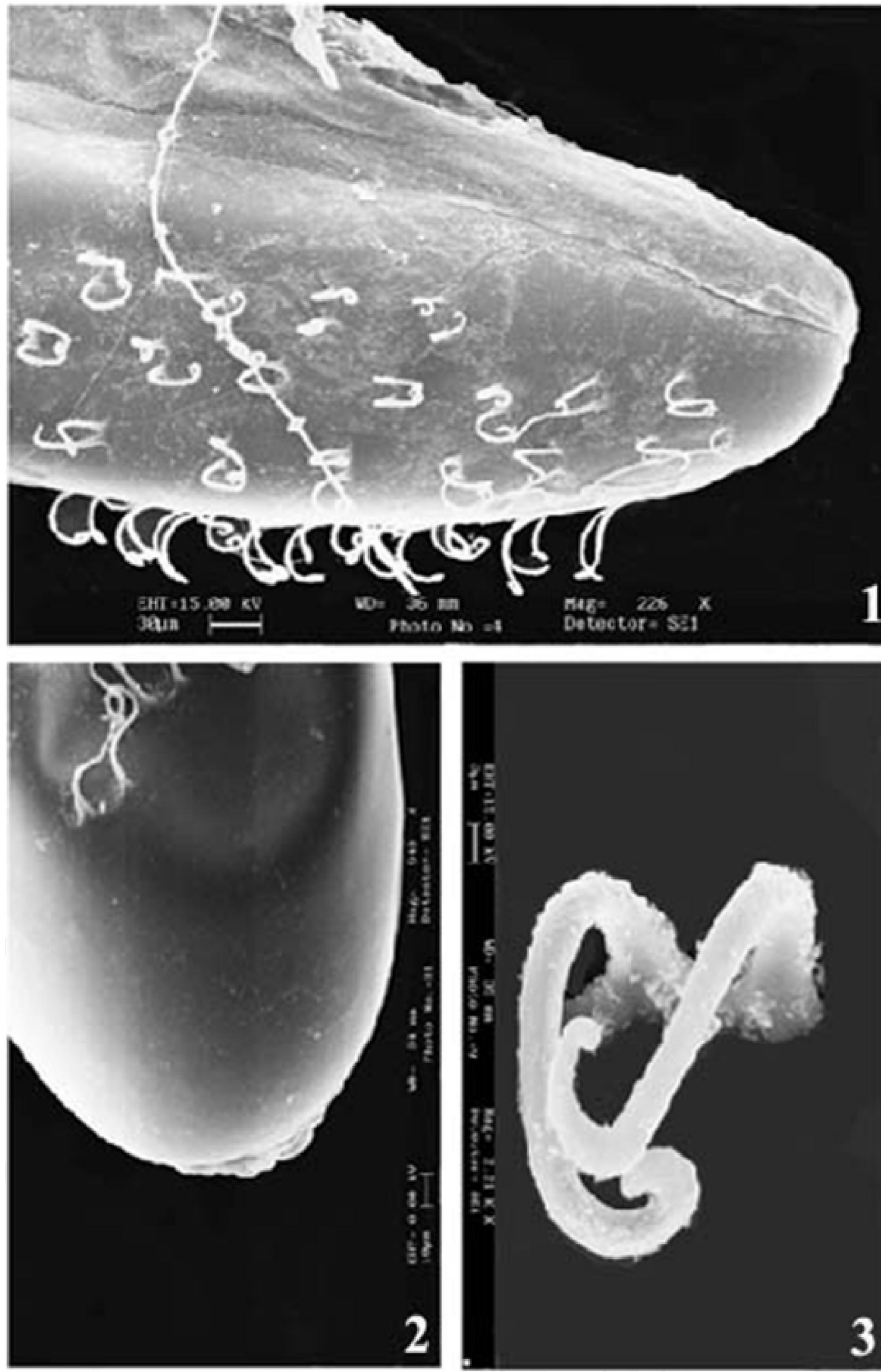

Plate II. SE M photographs of the eggs of Hohorsti ella rampurensis showing- 1. Enlarged posterior portion showing nature of apophyses X127, 2. Enlarged rear end showing the nature of stigma X460, 3. E nlarged view of apophyses in the middle region of the egg shell $\times 210$. 
and apically turned; apophyses occurring on the main egg shell occurred in pairs and remained bent. Moreover, the nature of opercular disc of $\mathrm{H}$. rampurensis was also different from that of $\mathrm{H}$. lata. The present study futrher supported the observations of Balter (1968 a) that egg morphology of avian lice can act as guide to louse taxonomy.

\section{ACKNOWLEDGEMENTS}

We thank to the Principal, Govt. Raza P. G. College, Rampur, India and Dr. A.K. Saxena, Department of Zoology, Govt. Raza P. G. College, Rampur, India for laboratory facilities.

\section{REFERENCES}

Balter, R.S. (1968a). Lice egg morphology as a guide to taxonomy. Medical Biology, 18:94-95.

Balter, R.S. (1968b). The microtopography of avian lice eggs. Medical Biology, 18: 166-179.

Beg, S.; Singh, S.K.; Kumar, S.; Gupta, N. and Saxena, A.K. (2004). Nature of egg shells of phthirapteran ectoparasites infesting House Crows. Rivista di Parassitologia, Vol. XXII (LXVI): N1

Bilinski, S.M. and Jankowska, W. (1987). Oogenesis in the bird louse (E omenacanthus stramineus (Insecta, Mallophaga). I. General description and structure of the egg capsule. Zoologische J ahrbuecher Abteilung fuer Anatomie und Ontogenie der Tiere, 116: 1-12.

Castro, D.D.C., Cicchnio, A. and Lareschi, M. (1996). Morfologia corionica de los huevos de Phthiraptera (Psocodae) parasitos de Cavia pamparum Thomas, 1917
(Rodentia, Caviidae). Revista brasileira Entomologia, 40(2): 211-220.

Gupta, N., Kumar, S., Saxena, A.K. and Bisht. K.L. (2004). Aspects of oviposition of an ischnoceran (Brueelia sp.) and an amblyceran (M yrsidea amandava) lice (Phthiraptera). National Seminar on Zoology and Human welfare.Dr. Shyama Prasad Mukherjee Government Degree College, Phaphamau, Allahabad, 204-210.

Gupta N., Khan, V., Kumar, S., Saxena, S., Rashmi, A. and Saxena, A.K. (2009). Eggshell morphology of selected Indian bird lice (Phthiraptera: Amblycera, Ischnocera). Entomological N ews, 120: 327-336.

Kumar, S., Badola, S., Singh, S.K., Gupta, N. and Saxena, A.K. (2003). Aspects of oviposition in duck louse, Anaticola crassicornis (Insecta, Ischnocera: Phthiraptera). Parasites and $\mathrm{D}$ iseases, 111-117.

Kumar, S., Gupta, N. and Saxena, A.K. (2007). Microtopography of the egg of two poultry lice (Phthiraptera). Indian Veterinary J ournal, 84: 578-580.

Rajput S., Gupta, N., Saxena, A.K. and Joshi, V.D. (2010). Microtopography of the egg shell of Menacanthus eurysternus (Phthiraptera: Amblycera). J ournal of Applied and Natural Science, 2:111-113.

Saxena, A.K., Singh, S.K., Surman, Kumar, A. and Badola, S. (2000). SEM studies on the microtopography of eggs of four pigeon lice (Phthiraptera, Insecta). Rivista di Parassitologia, XVII (LX1) N.3: 351-358.

Zadewaka, M., Jankowska, W. and Bilinski, S.M. (1997). Egg shells of mallophagans and anoplurans (Insecta: Phthiraptera): morphogenesis of specialized regions and the relation to F-action cytoskeleton of follicular cells. Tissue C ell 29: 665-673. 